\title{
Diversity, distribution and role of wild crucifers in major cabbage and kale growing areas of Kenya
}

\author{
R. Kahuthia-Gathu ${ }^{1,2}$, B. Löhr ${ }^{1}$, H.M. Poehling ${ }^{2 *}$ \\ and P.K. Mbugua ${ }^{3}$
}

${ }^{1}$ International Center of Insect Physiology and Ecology, PO Box 30772, 00100 Nairobi: ${ }^{2}$ Universität Hannover, Institute of Plant Protection and Plant Diseases, Herrenhäuser strasse 2, 30419 Hannover, Germany:

${ }^{3}$ Kenyatta University, Department of Plant \& Microbial Sciences, PO Box 48344, Nairobi

\begin{abstract}
An investigation of the diversity and distribution of wild crucifer species and their importance for cultivated crucifers was conducted during 2005 and 2006 in the highland and mid-altitude semi-arid areas of Kenya. Thirteen species of wild crucifers in nine genera were recorded: Raphanus raphanistrum, Erucastrum arabicum, Sisymbrium officinale, Crambe kilimandscharica, Capsella bursa-pastoris, Rorippa nudiuscula, Ro. micrantha, Ro. microphylla, Lepidium bonariense, Coronopus didymus, Brassica rapa, B. juncea and an unidentified Brassica species. Highland areas had significantly higher species diversity and species richness than midaltitude semi-arid areas. Species richness, diversity and evenness varied with season and location. Raphanus raphanistrum was the dominant non-cultivated species in the highlands followed by E. arabicum, which was also present and dominant in the semi-arid study sites. Diamondback moth (DBM) was recorded from ten wild crucifer species and R. raphanistrum and E. arabicum were the preferred host plant species. Overall, four larval, one larval-pupal and one pupal parasitoid of DBM were recorded: Diadegma semiclausum, D. mollipla, Apanteles sp., Cotesia plutellae, Oomyzus sokolowskii and Brachymeria species, respectively. Diadegma semiclausum was the most dominant species on all crucifers. We conclude that wild crucifers act as alternative hosts for DBM and provide refugia for DBM parasitoids, which risk local extinction through pesticide application or competition from introduced exotic parasitoid species. The wild crucifers also act as recolonization sites for DBM parasitoids.
\end{abstract}

Keywords: species diversity, parasitoids, diamondback moth, conservation biological control, cruciferous weeds, recolonization, agro-ecological systems

(Accepted 20 June 2008)

*Author for correspondence

Fax: 0049/511/762301

E-mail: Poehling@ipp.uni-hannover.de

\section{Introduction}

In natural and agricultural systems, species counts are used as a measure of diversity. Species diversity, however, is both a function of the number of species and the evenness in distribution of abundances of species (Magurran, 1988; Purvis \& Hector, 2000). Plant diversity affects the population 
dynamics of insect herbivores in agricultural (Andow, 1988) and natural communities (Karieva, 1983). Tahvanainen \& Root (1972) observed that adult beetles were more abundant on collards Brassica oleracea var. acephala grown in monocultures than on those grown adjacent to natural vegetation. The 'resource-concentration' hypothesis suggests that the higher herbivore abundance in pure stands is due to the higher probability of host location, long tenure time, higher feeding rates and greater reproductive success of herbivores with narrow host range. Agro-ecosystems that are more diverse in plant species and distribution have been reported to have higher diversity of arthropod communities including herbivore species, predators and parasitoids. In particular, the latter are of special importance in the conservation approach to biological control (Talekar \& Shelton, 1993; Kfir \& Thomas, 2001; Ohara et al., 2003). Earlier, Altieri (1984) observed that presence of weeds growing outside the crop fields contributed in keeping insect populations below the economic threshold. On the one hand, they provide refuges and, on the other, essential resources such as hosts/prey or alternative food sources (Dennis \& Fry, 1992; Landis et al., 2000; Norris \& Kogan, 2000). In the case of parasitoids, apart from being a source of hosts, flowering weeds can enhance longevity and effectiveness by providing pollen and nectar (Idris \& Grafius, 1995a; Baggen et al., 1999; Landis et al., 2000; Steffan-Dewenter et al., 2001). Wäckers \& van Rijn (2005) observed that nectar or pollen feeding is essential for the reproductive success of many insect predators and parasitoids. Varying rainfall amount and temperatures also increase or restrict the abundance of parasitoid species by determining the presence or absence of essential resources (Quayle et al., 2003). Thus, the assemblage of parasitoids in a particular habitat will depend on host-related and environment-related factors and might result in different degrees of biological control of pests.

The diamondback moth (DBM) Plutella xylostella Linnaeus (Lepidoptera: Plutellidae) is the most important pest of cultivated crucifers worldwide (Talekar \& Shelton, 1993; Reddy et al., 2004). DBM's exceptional pest status is due to the diversity and abundance of host plants, the frequent disruption of its natural enemies communities by broadspectrum pesticides, its high reproductive potential and genetic elasticity facilitating rapid development of pesticide resistance (Mohan \& Gujar, 2003; Shelton, 2004; Vickers et al., 2004). The pest has developed resistance to most chemical (Kibata, 1996) and bacterial insecticides (Liu et al., 1995; Tabashnik et al., 2003; Heckel et al., 2004; Sarfraz \& Keddie, 2005).

In a recent classical biological control effort, Diadegma semiclausum Hellén (Hymenoptera: Ichneumonidae) was imported from Taiwan and released in the highland areas of Kenya in June 2002. In addition, a Cotesia plutellae (Kurdjumov) (Hymenoptera: Braconidae) biotype from South Africa was released in 2004 in mid-altitude semi arid areas. Diadegma semiclausum has successfully established and is providing good control of DBM (Löhr et al., 2007). This has resulted in farmers reducing pesticide application while others have stopped spraying against DBM altogether in the highland areas where D. semiclausum was released (Löhr et al., 2007). However, C. plutellae has not established in the mid-altitude semi-arid areas; two years after its release very few individuals were recovered (Kahuthia-Gathu et al., unpublished data). However, even in areas with successful establishment, the stability of parasitoid populations is not assured. The presence of other cabbage pests, such as aphids, during the dry season might necessitate pesticide application (Oruku \& Ndung'u, 2001). The use of broadspectrum insecticides may be detrimental to the introduced parasitoids and result in pest resurgences as observed in Asia (Sastrosiswojo \& Sastrodihardjo, 1986; Verkerk \& Wright, 1997). We believe that the presence of wild crucifers in field margins can prevent large-scale elimination of parasitoids and, thus, stabilize the crucifer growing system.

The weeds introduce an element of biodiversity that expands the spectrum of natural enemies to colonize the crop as the host becomes available. The higher number of natural enemies entering the cabbage fields is related to higher species diversity (Cromartie Jr., 1975; Root \& Kareiva, 1984; Lamb, 1989). Pickett \& Thompson (1978) suggested that the disappearance of re-colonisation sources leads to extinction of dominant parasitoid populations. Weeds will act as alternative hosts and reservoirs for parasitoid species, which will colonise the cultivated crop, thus, enhancing biological control.

Agnew \& Agnew (1994) recorded 42 wild crucifers species in 19 genera in Kenya. However, their occurrence and distribution in major cabbage and kale growing areas is unknown. Even less known is the role they play in providing refugia for DBM and its parasitoids. Therefore, detailed surveys were conducted in two agro-ecological zones, highland rain-fed (mainly producing cabbage) and midaltitude semi-arid irrigated areas (mainly producing kale) to evaluate the diversity and distribution of wild crucifer species and their role for indigenous and exotic parasitoids. Plant species diversity and parasitoid assemblage from four sites in the two agro-ecological zones were compared to assess the influence of structural characteristics and pest management strategies on these beneficial insects.

\section{Materials and methods}

Study sites

Two sites each from major highland and mid-altitude semi-arid crucifer growing areas were selected for the studies. The highland sites were located in Central Province of Kenya and comprised of Naro Moru with an altitude ranging from 1893 to $2293 \mathrm{~m}$ and Kinangop from 2343 to $2749 \mathrm{~m}$. Maximum temperatures range between $22^{\circ} \mathrm{C}$ and $30^{\circ} \mathrm{C}$ and minimum temperatures between $10^{\circ} \mathrm{C}$ and $15^{\circ} \mathrm{C}$. The rainfall is bimodal and ranges from 1500 to $2000 \mathrm{~mm}$ per annum. The long rains occur between March and June and the short rains between October and December. Soils are mostly of volcanic origin and relatively fertile. Both cabbage and kale are grown in the region with the former being the dominant crop.

The mid-altitude semi-arid study areas were located in Eastern Province of Kenya and comprised of Yatta at 1220 to $1290 \mathrm{~m}$ and Athi River at 1457 to $1527 \mathrm{~m}$. Maximum temperatures range between $25^{\circ} \mathrm{C}$ and $32^{\circ} \mathrm{C}$ and minimum temperatures between $5^{\circ} \mathrm{C}$ and $20^{\circ} \mathrm{C}$. The areas receive 500 to $900 \mathrm{~mm}$ rainfall per annum and have no distinct seasons. Rainfall is unreliable and farmers supplement by irrigation. Black cotton soils are predominant in both areas. As temperatures are usually too high for head cabbage, kale is the crop grown in both areas. 


\section{Data collection}

Surveys were conducted quarterly during the hot dry (January-March), long rainy (April-June), cold dry (JulySeptember) and short rainy seasons (October-December) of 2005 and 2006. A total of 35 and 25 fields were selected in every visit from the highland and mid-altitude semi-arid areas, respectively, and used as the basis for evaluating the diversity of wild crucifers. In the highlands, sampling fields were selected at $2-4 \mathrm{~km}$ interval because of the large area under cabbage unlike in the mid-altitude areas where most of the kale fields were located close to each other along the river valley (Athi River) or irrigation canal (Yatta). A linetransect sampling technique previously described by GriegSmith (1983) was used to evaluate the diversity and distribution of wild crucifer species in the uncultivated land neighbouring the cabbage or kale fields. The representative wild crucifer species along a $30 \mathrm{~m}$ sampling line were sampled by placing a one-metre quadrat frame at the beginning of the transect and recording all wild crucifer species within the frame. The number of plants from each species within the frame was recorded. This procedure was repeated after every $3 \mathrm{~m}$ of the line transect to give a total of ten sampling points per transect. We tried to have the line transect perpendicular to the field margins. However, this was not always possible due to the small size of land left fallow and the generally small farm sizes. The number of quadrats varied because some of the selected fields had no wild crucifers recorded.

Samples from each crucifer species were collected and taken to the laboratory for processing and identification. The voucher specimens were identified using various plant identification keys (Ivens, 1967; Agnew \& Agnew, 1994). Species were confirmed and deposited at the East Africa Herbarium at National Museums of Kenya.

\section{Sampling of diamondback moth on wild crucifers}

To assess DBM incidence on the wild crucifers, a maximum of ten individual plants from each species were selected per quadrat and physically checked for the presence of DBM. The number of DBM larvae and pupae found on each plant were recorded. All 3rd and 4th instar DBM larvae and pupae were collected, kept in labelled (field number, host plant, locality, collection date) plastic containers and taken to the laboratory. The containers were lined with tissue paper at the bottom to absorb excess moisture and closed with a cap containing a fine muslin cloth to enhance ventilation and reduce mould growth. The larvae were kept at room temperature $\left(23 \pm 2^{\circ} \mathrm{C}\right), 50-70 \% \mathrm{RH}$ and a photoperiod of 12:12 h (L:D) and fed on their respective crucifer species when necessary until pupation. The pupae were then placed individually in clean plastic vials, plugged with cotton wool and observed daily for DBM or parasitoid emergence. The parasitoids species were identified, adults sexed and recorded. The number of parasitoids emerging from single cocoons in gregarious species was recorded.

\section{Data analysis}

The diversity and evenness of wild crucifer species was estimated using the Shannon Diversity Index $\left(\mathrm{H}^{\prime}\right)$. It is the proportion of species (pi) relative to the total number of species (S) summed up and multiplied by natural logarithm of this proportion (ln pi) (Magurran, 1988). The product is summed across species and multiplied by $(-1)$ (Rosenzweig, 1995). $\mathrm{H}^{\prime}=-p_{\mathrm{i}} \ln p_{\mathrm{i}}$, where $p_{\mathrm{i}},=n_{\mathrm{i}} / N$. Evenness was calculated by dividing $H^{\prime}$ by $\ln S$.

Variance in diversity was estimated using the formula

$$
\operatorname{Var} H^{\prime}=\left(p_{\mathrm{i}}-\left(\ln p_{\mathrm{i}}\right)^{2}-\left(p_{\mathrm{i}} \ln p_{\mathrm{i}}\right)^{2}\right) / N-\left(\mathrm{S}-1 / 2 N^{2}\right) \text {. }
$$

A $t$-test was performed to test for differences in diversity indices between seasons using the formula $t=H^{\prime} 1-H^{\prime} 2 /($ Var $\left.H^{\prime} 1+\operatorname{Var} H^{\prime} 2\right)^{1 / 2}$ (Batten, 1976; Magurran, 1988).

The data of DBM counts on wild crucifers were normalized using a square root transformation (SQRT +1$)$ before being subjected for analysis using a General Linear Model (GLM) procedure. Means were seperated using the Tukey test (SAS, 2004). Parasitism rates for solitary parasitoids were calculated as the sum of parasitoids divided by total number of adults $(\mathrm{DBM}+$ parasitoids $) \times 100$ while that of gregarious parastoids as sum of parasitised cocoons/(DBM+ cocoons) $\times 100$. The data for parasitoids recovered from the wild crucifers were arcsine SQRT transformed before anlaysis.

\section{Results}

\section{Diversity and distribution of wild crucifers}

Thirteen wild crucifer species from nine genera were recorded from over 480 fields sampled. A total of twelve species were recorded in the highlands and two species in the mid-altitude semi-arid areas. Erucastrum arabicum Fisch \& Mey., Raphanus raphanistrum L., Capsella bursa-pastoris (L.) Medic., Lepidium bonariense L., Crambe kilimandscharica O.E. Schulz., Coronopus didymus (L.) Sm., an unidentified Brassica sp., Brassica juncea (L.) Czern., Rorippa microphylla (Boenn. ex Rchb.) Hyl. ex A. Löve \& D. Löve, Brassica rapa L., Rorippa nudiuscula (Sond.) Thell. and Sisymbrium officinale (L.) Scop. were found in Kinangop and Naro Moru (tables 1 and 2). Rorippa micrantha (Roth.) Jonsell. and E. arabicum were the only species recorded in Yatta and Athi River. Due to the low numbers obtained, analysis on diversity was not done for the mid-altitude areas. Erucastrum arabicum was the only species recorded in both highlands and mid-altitude areas. Raphanus raphanistrum and E. arabicum were recorded throughout the sampling period of 2005 and 2006 in the highland areas of Naro Moru and Kinangop. Raphanus raphanistrum was the most dominant and abundant species in both highland areas. Rorippa nudiuscula and B. rapa were recorded from Kinangop only, but with very low frequencies.

A notable difference in species richness was observed between the highlands and mid-altitude semi-arid areas. The highlands recorded an average of six species while the average in mid-altitude areas was one species only. The average number of crucifer species was similar between the highland areas Kinangop and Naro Moru and also between mid-altitude semi-arid areas Athi River and Yatta (see also table 4).

Diversity indices and evenness differed significantly between seasons and regions. In Naro Moru, the diversity index ranged between 0.820 and 1.663 . The highest diversity indices of 1.663 and 1.050 were recorded during the short rains, while the lowest indices of 0.924 and 0.820 were recorded during the cold dry season in 2005 and 2006, respectively (table 1). In Kinangop, the highest indices of 
Table 1. Diversity index and seasonal occurrence of wild crucifer species in the highlands cabbage growing area of Naro Moru in Central Province of Kenya.

\begin{tabular}{|c|c|c|c|c|c|c|c|c|}
\hline \multirow[t]{2}{*}{ Crucifer species } & \multicolumn{4}{|c|}{ Number of quadrats with crucifers (2005) } & \multicolumn{4}{|c|}{ Number of quadrats with crucifers (2006) } \\
\hline & Hot dry & Long rains & Cold dry & Short rains & Hot dry & Long rains & Cold dry & Short rains \\
\hline Raphanus raphanistrum & 52 & 158 & 102 & 112 & 90 & 155 & 134 & 233 \\
\hline Rorippa nudiuscula & - & - & - & - & - & - & - & - \\
\hline Brassica juncea & 4 & - & - & - & - & - & - & 10 \\
\hline Capsella bursa-pastoris & 31 & 5 & 2 & 14 & - & - & 2 & 7 \\
\hline Lepidium bonariense & 16 & 4 & 5 & 9 & 10 & 30 & - & 28 \\
\hline Sisymbrium officinale & - & - & 3 & - & - & 4 & 10 & - \\
\hline Crambe kilimandscharica & - & 4 & - & - & - & - & - & - \\
\hline Brassica sp. & - & 4 & - & - & - & - & - & - \\
\hline Number of species & 5 & 6 & 6 & 5 & 4 & 4 & 4 & 6 \\
\hline Total number of quadrats & 169 & 292 & 144 & 250 & 150 & 214 & 201 & 361 \\
\hline Diversity index & 1.353 & 0.956 & 0.924 & 1.663 & 0.886 & 0.886 & 0.820 & 1.050 \\
\hline
\end{tabular}

Table 2. Diversity index and seasonal occurrence of wild crucifer species in the highlands cabbage growing area of Kinangop in Central Province of Kenya.

\begin{tabular}{|c|c|c|c|c|c|c|c|c|}
\hline \multirow[t]{2}{*}{ Crucifer species } & \multicolumn{4}{|c|}{ Number of quadrats with crucifers (2005) } & \multicolumn{4}{|c|}{ Number of quadrats with crucifers (2006) } \\
\hline & Hot dry & Long rains & Cold dry & Short rains & Hot dry & Long rains & Cold dry & Short rains \\
\hline Raphanus raphanistrum & 136 & 262 & 265 & 180 & 101 & 244 & 186 & 284 \\
\hline Rorippa nudiuscula & 7 & - & - & - & - & - & - & - \\
\hline Brassica juncea & 3 & - & - & - & - & - & 4 & 31 \\
\hline Capsella bursa-pastoris & 32 & 30 & 32 & 25 & - & 40 & 23 & - \\
\hline Lepidium bonariense & 2 & 5 & 1 & 2 & & 4 & 4 & 19 \\
\hline Coronapus didymus & 10 & - & 7 & 22 & 6 & 7 & 14 & 11 \\
\hline Sisymbrium officinale & - & - & - & - & - & 1 & 15 & - \\
\hline Crambe kilimandscharica & - & 10 & 10 & - & - & & 3 & - \\
\hline Brassica rapa & - & - & - & - & - & 5 & - & - \\
\hline Species no. & 8 & 6 & 6 & 5 & 3 & 7 & 8 & 6 \\
\hline Total number of quadrats & 210 & 346 & 346 & 241 & 114 & 334 & 253 & 386 \\
\hline Diversity index & 1.203 & 0.896 & 0.839 & 0.861 & 0.434 & 0.927 & 1.021 & 0.989 \\
\hline
\end{tabular}

1.203 and 1.021 were recorded during the hot dry and cold dry seasons, and the lowest indices of 0.839 and 0.434 were recorded during the hot dry and cold dry seasons in 2005 and 2006, respectively (table 2). Highest species evenness of 0.841 and 0.639 was recorded during the hot dry season, while lowest evenness of 0.526 and 0.494 was recorded during cold dry and long rain seasons in 2005 and 2006, respectively, in Naro Moru. However, the highest species evenness of 0.578 and 0.552 was recorded during the hot dry and short rainy season, while the lowest species evenness of 0.468 and 0.395 was recorded during cold dry and hot dry season in 2005 and 2006, respectively, in Kinangop.

Species diversity differed significantly between hot dry and long rainy season of $2005(t=6.01, n=448, P<0.001)$, between short rainy and dry season of 2005-2006 $(t=8.9$, $n=363, P<0.001)$ and between cold dry and short rainy season of $2006(t=3.18, n=511, P<0.001)$ in Naro Moru (table 1). In the Kinangop area, significant differences were observed between hot dry and long rainy season of 2005 $(t=3.09, n=439, \quad P<0.001)$ and $2006 \quad(t=4.88, n=245$, $P<0.001)$, respectively, and between short rainy and hot dry season of 2005-2006 $(t=4.10, n=114, P<0.001)$ (table 2).

Species diversity indices and species richness for Yatta and Athi River were not calculated since only two crucifer species were recorded and the number of quadrats containing a particular species was too low. At certain periods, no wild crucifer species was recorded from the quadrats.

\section{Incidence of DBM on wild crucifers}

Diamondback moth was collected from ten out of the 12 wild crucifers recorded in the highlands, while no DBM was found on $C$. didymus and B. rapa (tables 3 and 4). The pest was present on $R$. raphanistrum throughout the sampling period. In 2006, the highest population of 1.03 DBM per plant 
Table 3. Seasonal variation on mean number of diamondback moth per plant \pm SE on wild crucifer species in the highland crucifer growing areas of Naro Moru from Central Province of Kenya.

\begin{tabular}{|c|c|c|c|c|c|c|c|c|}
\hline \multirow[t]{2}{*}{ Wild crucifer species } & \multicolumn{4}{|c|}{ Number of DBM per plant in 2005} & \multicolumn{4}{|c|}{ Number of DBM per plant in 2006} \\
\hline & Hot dry & Long rains & Cold dry & Short rains & Hot dry & Long rains & Cold dry & Short rains \\
\hline Raphanus raphanistrum & $\begin{array}{c}0.03 \pm 0.03 \\
n=423\end{array}$ & $\begin{array}{c}0.06 \pm 0.02 \\
n=715\end{array}$ & $\begin{array}{c}1.08 \pm 0.27 \\
n=200\end{array}$ & $\begin{array}{c}0.07 \pm 0.04 \\
n=419\end{array}$ & $\begin{array}{c}0.09 \pm 0.05 \\
n=341\end{array}$ & $\begin{array}{c}0.45 \pm 0.14 \\
n=491\end{array}$ & $\begin{array}{c}0.21 \pm 0.06 \\
n=354\end{array}$ & $\begin{array}{c}0.12 \pm 0.02 \\
n=1193\end{array}$ \\
\hline Eucastrum arabicum & $\begin{array}{c}0.15 \pm 0.11 \\
n=162\end{array}$ & $\begin{array}{c}0.06 \pm 0.03 \\
n=362\end{array}$ & $\begin{array}{c}0.16 \pm 0.08 \\
n=26\end{array}$ & $\begin{array}{c}0 \\
n=26\end{array}$ & $\begin{array}{c}0 \\
n=259\end{array}$ & $\begin{array}{c}0.11 \pm 0.11 \\
n=25\end{array}$ & $\begin{array}{c}0.009 \pm 0.01 \\
n=151\end{array}$ & $\begin{array}{c}0.02 \pm 0.01 \\
n=156\end{array}$ \\
\hline Brassica juncea & $\begin{array}{c}0 \\
n=5\end{array}$ & - & - & - & - & - & - & $\begin{array}{c}0.22 \pm 0.20 \\
n=10\end{array}$ \\
\hline Lepidium bonariense & $\begin{array}{c}0.07 \pm 0.06 \\
n=56\end{array}$ & $\begin{array}{c}0 \\
n=4\end{array}$ & $\begin{array}{c}0 \\
n=5\end{array}$ & $\begin{array}{c}0 \\
n=9\end{array}$ & $\begin{array}{c}0 \\
n=15\end{array}$ & $\begin{array}{c}0.25 \pm 0.25 \\
n=30\end{array}$ & - & $\begin{array}{c}0 \\
n=37\end{array}$ \\
\hline Rorippa microphylla & - & - & $\begin{array}{c}0 \\
n=7\end{array}$ & - & 0 & - & - & $\begin{array}{c}1.25 \pm 0.63 \\
n=8\end{array}$ \\
\hline Coronopus didymus & - & - & - & $\begin{array}{c}0 \\
n=6\end{array}$ & $\begin{array}{c}0 \\
n=2\end{array}$ & - & - & - \\
\hline Brassica sp. & - & $\begin{array}{c}0 \\
n=4\end{array}$ & - & - & - & - & - & - \\
\hline Number of DBM sampled & 60 & 47 & 155 & 21 & 16 & 223 & 81 & 172 \\
\hline
\end{tabular}

Table 4. Seasonal variation on mean number of diamondback moth per plant \pm SE on wild crucifer species in the highland crucifer growing areas of Kinangop from Central Province of Kenya.

\begin{tabular}{|c|c|c|c|c|c|c|c|c|}
\hline \multirow[t]{2}{*}{ Wild crucifer species } & \multicolumn{4}{|c|}{ Number of DBM per plant in 2005} & \multicolumn{4}{|c|}{ Number of DBM per plant in 2006} \\
\hline & Hot dry & Long rains & Cold dry & Short rains & Hot dry & Long rains & Cold dry & Short rains \\
\hline Raphanus raphanistrum & $\begin{array}{c}0.84 \pm 0.29 \\
n=390\end{array}$ & $\begin{array}{c}0.29 \pm 0.07 \\
n=262\end{array}$ & $\begin{array}{c}0.19 \pm 0.04 \\
n=549\end{array}$ & $\begin{array}{c}0.91 \pm 0.25 \\
n=314\end{array}$ & $\begin{array}{c}1.03 \pm 0.59 \\
n=168\end{array}$ & $\begin{array}{c}0.09 \pm 0.02 \\
n=1522\end{array}$ & $\begin{array}{c}0.37 \pm 0.09 \\
n=590\end{array}$ & $\begin{array}{c}0.29 \pm 0.06 \\
n=1077\end{array}$ \\
\hline Eucastrum arabicum & $\begin{array}{c}0.13 \pm 0.13 \\
n=14\end{array}$ & $\begin{array}{c}0.17 \pm 0.17 \\
n=45\end{array}$ & $\begin{array}{c}0.53 \pm 0.49 \\
n=49\end{array}$ & $\begin{array}{c}0 \\
n=17\end{array}$ & $\begin{array}{c}0 \\
n=7\end{array}$ & $\begin{array}{c}0.05 \pm 0.03 \\
n=94\end{array}$ & $\begin{array}{c}0 \\
n=4\end{array}$ & $\begin{array}{c}0.15 \pm 0.15 \\
n=25\end{array}$ \\
\hline Rorippa nudiuscula & $\begin{array}{c}0.74 \pm 0.42 \\
n=95\end{array}$ & - & - & - & - & - & - & - \\
\hline Capsella bursa-pastoris & $\begin{array}{c}0.12 \pm 0.09 \\
n=95\end{array}$ & $\begin{array}{c}0 \\
n=43\end{array}$ & $\begin{array}{c}0 \\
n=32\end{array}$ & $\begin{array}{c}0 \\
n=26\end{array}$ & - & $\begin{array}{c}0 \\
n=99\end{array}$ & $\begin{array}{c}0 \\
n=25\end{array}$ & $\begin{array}{c}0 \\
n=55\end{array}$ \\
\hline Lepidium bonariense & $\begin{array}{c}0 \\
n=4\end{array}$ & $\begin{array}{c}0 \\
n=6\end{array}$ & $\begin{array}{c}0 \\
n=1\end{array}$ & $\begin{array}{c}0 \\
n=2\end{array}$ & - & $\begin{array}{c}0 \\
n=4\end{array}$ & $\begin{array}{c}0 \\
n=4\end{array}$ & $\begin{array}{c}0 \\
n=25\end{array}$ \\
\hline Rorippa microphylla & $\begin{array}{c}1.70 \pm 0.67 \\
n=21\end{array}$ & $\begin{array}{c}0.70 \pm 0.42 \\
n=16\end{array}$ & - & - & - & - & - & $\begin{array}{c}0.49 \pm 0.37 \\
n=35\end{array}$ \\
\hline Crambe kilimandscharica & - & $\begin{array}{c}1.20 \pm 0.55 \\
n=10\end{array}$ & $\begin{array}{c}0 \\
n=10\end{array}$ & - & - & - & $\begin{array}{c}1.68 \pm 1.43 \\
n=18\end{array}$ & - \\
\hline Brassica rapa & - & - & - & - & - & $\begin{array}{c}0 \\
n=15\end{array}$ & - & - \\
\hline Number of DBM sampled & 330 & 240 & 99 & 251 & 226 & 110 & 265 & 313 \\
\hline
\end{tabular}

was recorded during the hot dry season in Kinangop and, in 2005 during the cold dry season in Naro Moru, 1.08 DBM per plant, both from $R$. raphanistrum. The highest population of $0.66 \mathrm{DBM}$ per plant was recorded during the long rainy season of 2005 in Athi River from E. arabicum. No DBM was collected from E. arabicum and Ro. micrantha in Yatta during 2005 (table 5).

\section{Parasitoid fauna on wild crucifers}

Six primary parasitoid species were recovered from DBM larvae or pupae collected from seven wild crucifers species (table 6). Four larval parasitoid species, D. semiclausum and Diadegma mollipla (Holmgren) (both Hymenoptera: Ichneumonidae), Cotesia plutellae (Kurdjumov) and Apanteles 
Table 5. Seasonal variation on mean number of diamondback moth per plant \pm SE on wild crucifer species in two mid-altitude semi-arid crucifer growing areas of Athi River and Yatta from Eastern Province of Kenya.

\begin{tabular}{|c|c|c|c|c|c|c|c|c|}
\hline Crucifer species & \multicolumn{4}{|c|}{ Number of DBM per plant in 2005} & \multicolumn{4}{|c|}{ Number of DBM per plant in 2006} \\
\hline \multicolumn{9}{|l|}{ Athi River } \\
\hline Ro. micrantha & - & - & - & $\begin{array}{c}0 \\
n=6\end{array}$ & - & $\begin{array}{c}0 \\
n=25\end{array}$ & $\begin{array}{c}0 \\
n=105\end{array}$ & $\begin{array}{c}0.002 \pm 0.002 \\
n=435\end{array}$ \\
\hline E. arabicum & - & $\begin{array}{c}0 \\
n=3\end{array}$ & $\begin{array}{c}0 \\
n=1\end{array}$ & - & - & $\begin{array}{c}0 \\
n=12\end{array}$ & - & - \\
\hline Ro. micrantha & - & $\begin{array}{c}0 \\
n=15\end{array}$ & $\begin{array}{c}0 \\
n=65\end{array}$ & - & $\begin{array}{c}0.25 \pm 0.25 \\
n=10\end{array}$ & $\begin{array}{c}0.17 \pm 0.05 \\
n=164\end{array}$ & $\begin{array}{c}0 \\
n=63\end{array}$ & $\begin{array}{c}0.02 \pm 0.02 \\
n=227\end{array}$ \\
\hline DBM sampled & & 0 & 0 & & 4 & 10 & 0 & 7 \\
\hline
\end{tabular}

Table 6. Parasitism rates \pm SE and parasitoid species recovered from diamondback moth collected from wild crucifers in highland crucifer growing areas of Central Province and mid-altitude semi-arid areas of Eastern Province of Kenya. Means \pm SE followed by same letters within a column are not significantly different at $P<0.05$ (SNK).

\begin{tabular}{|c|c|c|c|c|c|c|c|c|}
\hline \multirow[t]{2}{*}{ Site } & \multirow[t]{2}{*}{ Parasitoid species } & \multicolumn{7}{|c|}{ Percent parasitism \pm SE on wild crucifer species } \\
\hline & & $\begin{array}{c}\text { Raphanus } \\
\text { raphanistrum }\end{array}$ & $\begin{array}{c}\text { Erucastrum } \\
\text { arabicum }\end{array}$ & $\begin{array}{l}\text { Brassica } \\
\text { juncea }\end{array}$ & $\begin{array}{l}\text { C. bursa- } \\
\text { pastoris }\end{array}$ & $\begin{array}{l}\text { Rorippa } \\
\text { microphylla }\end{array}$ & $\begin{array}{l}\text { Sisymbrium } \\
\text { officinale }\end{array}$ & $\begin{array}{c}\text { Crambe } \\
\text { kilimandscharica }\end{array}$ \\
\hline Athi River & $\begin{array}{l}\text { D. semiclausum } \\
\text { D. mollipla } \\
\text { Apanteles sp. } \\
\text { Brachymeria sp. } \\
\text { O. sokolowskii } \\
\text { C. plutellae } \\
\text { DBM collected }(n)\end{array}$ & & $\begin{array}{c}7.4 \pm 2.9 \mathrm{a} \\
10.4 \pm 3.5 \mathrm{a} \\
9.24 \pm 3.5 \mathrm{a} \\
0.2 \pm 0.2 \mathrm{c} \\
1.0 \pm 0.7 \mathrm{bc} \\
1.3 \pm 0.9 \mathrm{~b} \\
265\end{array}$ & & & & & \\
\hline
\end{tabular}

sp. (both Hymenoptera: Braconidae), one larval-pupal parasitoid Oomyzus sokolowskii (Kurdjumov) (Hymenoptera: Eulophidae) and one pupal parasitoid (Brachymeria sp., Hymenoptera: Chalcidae) were collected. Whereas in the highland areas only D. semiclausum, D. mollipla and O. sokolowskii could be found, all six species mentioned above were recovered from E. arabicum in the mid-altitude semi-arid area of Athi River. The highest parasitism rates in the highlands were observed on Ro. microphylla, followed by $R$. raphanistrum, C. bursa-pastoris and E. arabicum. In midaltitude semi-arid areas, parasitoids were recovered in Athi River only, from DBM collected from E. arabicum. Diadegma semiclausum was the dominant and abundant species in the highlands representing over $80 \%$ of the total number recorded, whereas at Athi River D. mollipla was the dominant species. However, parasitism was lower than in the highlands.

\section{Discussion}

The importance of landscape aspects and, particularly, diversity of plant species in areas surrounding crop fields, for the management of crop pests, has received considerable attention. Higher plant diversity is assumed to enhance the population of natural enemies, which migrate to crop fields, attack the pests and, thereby, contribute to better pest control (Root, 1973; Boller et al., 2004; Bullock et al., 2007; Olson \& Wackers, 2007; Yann et al., 2007). Comparing the literature (from other agroecosystems) and our data, the most logical deduction, from the practical point of view, is that the existence of wild crucifers in the vicinity of cabbage and kale fields can be expected to provide the capacity for recolonization after disturbance, or resilience (Bengtsson et al., 2003; Tscharntke et al., 2005). Hickman \& Wratten (1996) and Dyer \& Landis (1997) related the number of natural enemies entering the crop field to higher diversity of vegetation surrounding wheat and maize fields, respectively.

Higher species richness of wild crucifers and higher species dominance by particular species was observed in the highland than mid-altitude semi-arid growing areas. Variation in species diversity and richness has been attributed to differences in amount of rainfall, soil type and altitude gradient (Cowling, 1996; Montana \& Valiente-Banuet, 1998; Suddarapandian \& Swamp, 2000). Simmons \& Cowling 
(1996) observed that species diversity changed along soil fertility and geographical gradients in South Africa's Cape Peninsula. Thompson et al. (2005) suggests that the species richness of a community is determined by the soil fertility. This could have applied in our research because the highlands had rich volcanic soils and this is where higher species diversity was recorded. The higher species diversity in Kinangop than in Naro Moru can be attributed to higher altitude and more rainfall in the former. Higher species diversity recorded mainly during the hot dry season was attributed to most of the farmers leaving their land fallow, especially where there was no water to supplement rainfall. The strong influence of seasons on the abundance and diversity of wild crucifers in the highland is a good indication of the relevance of rainfall. In contrast, only two species were found in the semi-arid areas. Their abundance fluctuated less between the seasons and, thus, they seem to be much better adapted to water stress than most highland species. Erucastrum arabicum was the only species found growing in both highland and semi-arid areas and was codominant in the former and dominant in the latter. We assume that adaptation to growing in dry conditions is a rare trait in crucifers and this is most likely a key factor responsible for low species diversity in the semi-arid areas. This might also explain why Ro. micrantha was only found growing in areas of continuous water flow. Species richness in mid-altitude semi-arid areas was limited by water scarcity as observed by Montana \& Valiente-Banuet (1998).

Under the 'enemies hypothesis' (Root, 1973; Russell, 1989; Wolfe, 2002), weeds introduce an element of biodiversity that expands the spectrum of natural enemies to colonize the crop (Longley et al., 1997). The hypothesis predicts a positive correlation between plant species richness and natural enemy abundance, which results in the regulation of herbivores at lower levels in diverse vegetation than in pure stands. Weeds are an important part of the vegetative diversity and help in maintaining and augmenting natural enemy populations (Landis et al., 2000; Hooks \& Johnson, 2003, Norris \& Kogan, 2005). Weeds can be even more important when they share pests and natural enemies with the cultivated crop (Tscharntke \& Kruess, 1999; Kremen et al., 2002). This is of special importance in a 'crucifer system' because of the relative strong association of herbivores and their most efficient specialized natural enemies, such as the parasitoids, to a narrow host plant range. Of all wild crucifers collected, $R$. raphanistrum was the most dominant and abundant species in the highlands, and it was also observed to flower for extended periods. Importance of flowering plants to parasitoids in providing nectar and pollen in crucifer growing systems has been documented (Idris \& Grafius, 1995b; Winkler et al., 2005). They observed that wildflowers increased the longevity and fecundity of $D$. insulare while Lee et al. (2006) observed that presence of flowering crucifers inside cabbage fields increased parasitism rates. In other studies, Diadegma semiclausum showed significant differences in longevity when provided with different sugar solutions (Winkler et al., 2005). This is in accordance with many reports stressing the importance of carbohydrate-rich foods for adult insects.

Russell (1989) postulated that the closer the companion plants are to the crop the more effective they are in regulating pest populations because some natural enemies have only a limited spatial dispersal potential. Therefore, the small farm sizes and proximity of wild crucifer species to cultivated crucifer crops in Kenya might favour the natural management of DBM since wild crucifers in boundary vegetation could provide a complete set of important resources for parasitoids such as hosts and nutrition (e.g. nectar). Possibly, wild crucifers in uncultivated areas will also provide reservoirs of the pest levelling off the positive effect for the parasitoid population. However, DBM popuations on the wild crucifers were always much lower $(1: 5)$ compared to that reported on cultivated crucifer crop (Löhr et al., 2007; Kahuthia-Gathu et al., in press). Karieva (1983) and Andow (1988) observed that specialist herbivores exhibit lower population densities in diverse habitats containing host plants and non-host plants compared with simple monoculture areas covered by host plants only. This might be due to higher probability of host location, host finding, higher feeding rates and greater reproductive success of the herbivores. The low DBM numbers on wild crucifers could also be associated with higher species diversity and high predation in the uncultivated areas. Some of the wild crucifers being relatively smaller than the cultivated cultivars could have affected the DBM numbers. A variety of predators, including spiders, were found feeding on the DBM. The results are supported by the findings of Liljesthrom et al. (2003), who found that spiders were more abundant in uncultivated insecticide-free areas. Also, in our study we found many natural enemies, especially predators on the wild crucifers, but their abundance was not quantified. We hypothesize that the off crop areas provide only a minor risk of being a substantive source for the pests and that their function to stabilize the parasitoid populations is overweighing. However, this must remain speculative until a broad comparison between field plots, with and without neighbouring off crop areas, is performed.

The number of parasitoids recorded in the cabbage growing areas was significantly higher than in kale growing areas. Out of the total 2441 and 3545 DBM collected from Naro Moru and Kinangop, 1520 and 1704 parasitoids emerged, respectively; while in Athi River and Yatta, 962 and 649 parasitoids emerged from 2756 and 1649 DBM collected, respectively. These differences could be due to continuous cabbage growing all the year round and an abundance of wild crucifer species. Parasitoids strongly respond to vegetation complexity (Marino \& Landis, 1996). The difference in parasitoid numbers and assemblage may be related to climatic variations between the two agroecological zones. The continuous cropping in the highlands may offer a more stable environment where both DBM and its parasitoids can co-exist for a long time. The large patches with wild crucifers observed in the cabbage growing areas may have contributed to high parasitoid abundance. Thies \& Tscharntke (1999) described increasing parasitism of rape pollen beetle in non-crop habitat area. Kruess \& Tscharntke (2000) observed that percent parasitism of the weevil Oxystoma ochropus increased with area, doubling from 35\% on the smallest to $70 \%$ on the largest meadows. As mentioned above, one key factor supporting parasitoid abundance and efficacy is the supply of convenient food for the adults. Stapel et al. (1997) ascertained that female Microplitis croceipes Cresson (Hymenoptera: Braconidae), a larval parasitoid of Helicoverpa zea Boddie (Lepidoptera: Noctuidae), stayed longer and parasitised more host larvae on patches of nectaried cotton plants than on nectariless cotton plants. Zhao et al. (1992) observed that parasitism of 
DBM by D. insulare (Cresson) (Hymenoptera: Ichneumonidae) was higher in broccoli fields adjacent to nectarproducing plants than in broccoli fields that were not surrounded by nectar producing plants.

A surprising result in our study was the very low occurrence of the endemic parasitoid species D. mollipla. This species was recovered almost entirely from the wild crucifers and kale, none from Naro Moru and only one parasitoid wasp from Kinangop on cabbage. Diadegma mollipla is considered to be a relative generalist, the species is reported to be indigenous to eastern and southern Africa; and, apart from attacking DBM, it is also known as a parasitoid of potato tuber moth (PTM) Phthorimaea operculella (Zeller) (Lepidoptera: Gelechiidae) on potato and tobacco in southern Africa and on potato in Yemen (Kroschel, 1993). The original host of D. mollipla is unknown (Gupta, 1974; Azidah et al., 2000) since PTM is an introduced species to Africa. Oduor et al. (1996) observed that D. mollipla was an abundant and widely distributed parasitoid of DBM in eastern African highlands. Overall, field parasitism was less than 20\%, with D. mollipla accounting for $9 \%$. One reason could be a lack of strong intrinsic cues from the typical crucifer host plants of DBM. This may also explain the generally low parasitism rates observed in the laboratory on crucifers (Akol et al., 2003). Moreover, Rossbach et al. (2005) observed that D. mollipla was not attracted by the chemical odours produced by kale, and this could have also contributed to the low parasitism. The parasitoid also has been recovered from DBM on snowpeas, where significantly higher parasitism rates were recorded compared to that of DBM on cabbage (Löhr \& Rossbach, 2004). This might be due to the host plant not being attractive to the other DBM parasitoids. Momanyi et al. (2006) and Löhr et al. (2007) observed that D. semiclausum is very competitive and displaced indigenous parasitoids from cabbage fields even before it had become firmly established in the highlands of Kenya. Absence of D. mollipla on cabbage in the highlands two years after the introduction of $D$. semiclausum may indicate the stiff competition this species is facing from D. semiclausum, a DBM specialist with a high searching efficiency (Wang \& Keller, 2002). This could have forced D. mollipla to search for DBM from the wild crucifers, which are the alternative hosts; consequently, significant numbers of $D$. mollipla were collected in the highlands and semi-arid areas on the wild crucifers only. Oomyzus sokolowskii is a gregarious larvalpupal parasitoid that attacks DBM (Fitton \& Walker, 1992) and has been introduced in tropical and subtropical regions to control DBM (Talekar \& Hu, 1966) and is adapted to high temperature conditions. They were abundant in the midaltitude semi-arid areas throughout the sampling period, while in the highlands their occurrence was mainly during the hot seasons. Parasitism rates ranged between $0 \%$ and $21.2 \%$ in the mid-altitude semi-arid areas and $0 \%$ and $1.2 \%$ in the highlands. Parasitism by $O$. sokolowskii decreased with the increase in parasitism rates by D. semiclausum. This could be due to the low numbers of 4th instar DBM larvae and pupae available for O. sokolowskii to parasitize.

Much to our surprise, D. semiclausum, considered a parasitoid for cool highland areas (Talekar \& Shelton, 1993), was recovered from the mid-altitude semi-arid areas that are hot and dry. The large numbers recovered show that the parasitoid can thrive under these conditions, even though their seasonality indicates their susceptibility to high temperature, relative humidity and vapour pressure deficit
(VPD). Since March 2005 when Cotesia plutellae was released in Yatta and Athi River, very low numbers have been recovered from the kale fields. On the contrary, the parasitoid has become established within the Lake Victoria region and spread over $200 \mathrm{~km}$ from the release sites in Uganda into western Kenya (ICIPE, unpublished data). Remarkable, also, is the complete absence of hyperparasitoids in both highland and mid-altitude semi-arid areas, which may have contributed to the successful establishment and spread of D. semiclausum.

In conclusion, wild crucifer species will play an important role in Kenya in the conservation and enhancement of parasitoid populations by providing refugia in times of absence of the crop, a reservoir for recolonization of fields after local elimination of parasitoids. The more diverse ecosystem helps to stabilize the pest population by favouring density-dependent responses of the pest's natural enemies. Furthermore, they seem to conserve indigenous parasitoid species that were displaced from cultivated areas after the introduction of a superior competitor.

\section{Acknowledgement}

We wish to thank the German Federal Ministry of Economic Cooperation and Development (BMZ) for sponsoring the diamondback moth bio-control project through the German Agency of Technical Cooperation (GTZ). Our sincere gratitude to Timothy Mathenge from Nairobi University who accompanied us to the field and assisted in identification of the wild crucifers and Geoffrey Mungai of East African herbarium who confirmed the voucher specimens. Special thanks to Eric Muchugu, Glenn Sequira and Anthony Wanjoya for assisting in the analysis of data. The entire DBM bio-control project staff, especially Faith Nyamu and Raphael Mukiti, is acknowledged for their assistance and technical support. F. Schulthess and Subramanian are acknowledged for their great assistance on the manuscript. We also thank the agricultural extension officers for their field support during the study and the farmers for allowing us to use their farms.

\section{References}

Agnew, A.D.Q. \& Agnew, S. (1994) Upland Kenya Wild Flowers. A Flora of the Ferns and Herbaceous Flowering Plants of Upland Kenya. 374 pp. Nairobi, Kenya, East Africa Natural History Society.

Akol, A.M., Njagi, P.G.N., Sithanantham, S. \& Mueke, J.M. (2003) Effects of two neem insecticide formulations on attractiveness, acceptability and suitability of diamondback moth larvae to parasitoid Diadegma mollipla (Holmgren) (Hymenoptera: Ichneumonidae). Journal of Applied Entomology 127, 325-331.

Altieri, M.A. (1984) Patterns of insect diversity in monocultures and polycultures of Brussel sprouts. Protection Ecology 6, 227-232.

Andow, D.A. (1988) Management of weeds for insect manipulation in agroecosystems. pp. 265-301 in Altieri M.A. \& Liebman M.Z. (Eds) Weed Management in Agroecosystems: Ecological Approaches. Boca Raton, FL, CRC Press.

Azidah, A.A., Fitton, M.G \& Quicke, D.L.J. (2000) Identification of the Diadegma species (Hymenoptera: Ichneumonidae, Campopleginae) attacking the diamondback moth, Plutella 
xylostella (Lepidoptera: Plutellidae). Bulletin of Entomological Research 90, 375-389.

Baggen, L.R., Gurr, G.M. \& Meats, A. (1999) Flowers in tritrophic systems: mechanisms allowing selective exploitation by insect natural enemies for conservation biological control. Entomologia Experimentalis et Applicata 91, 155-161.

Batten, L.A. (1976) Bird community of some Killarney woodlands. Proceedings of Royal Irish Academy 76, 285-313.

Bengtsson, J., Angelstam, P., Elmquvist, T., Emanuelsson, U., Forbes, C. \& Ihse, M. (2003) Reserves, resilience and dynamic landscapes. Ambio 32, 389-396.

Boller, E.F., Hani, F. \& Poehling, H.-M. (2004) Ecological Infrastructures: Idea book on Functional Biodiversity at the Farm Level. 213 pp. Lindau, Switzerland, LBL.

Bullock, J.M., Pywell, R.F. \& Walkers, K.J. (2007) Long-term enhancement of agricultural production by restoration of biodiversity. Journal of Applied Ecology 44, 6-12.

Cowling, R.M. (1996) Diversity components in a rich-species area of the Cape Floristic Region. Journal of Vegetation Science 83, 699-710.

Cromartie Jr., W.J. (1975) The effect of stand size and vegetational background on the colonization of cruciferous plants by herbivorous insects. Journal of Applied Ecology 12, 517-533.

Dennis, P. \& Fry, G.L.A. (1992) Field margins, can they enhance natural enemy population densities and general arthropod diversity on farmland? Agricultural Ecosystems of Environment 40, 95-115.

Dyer, L.E. \& Landis, D.A. (1997) Influence of non-crop habitats on the distribution of Eriborus terebrons (Hymenoptera: Ichneumonidae) in cornfields. Environmental Entomology 26, 924-932.

Fitton, M. \& Walker, A. (1992) Hymenopterous parasitoids associated with diamondback moth: the taxonomic dilemma. pp. 225-232 in Talekar, N.S. (Ed.) Diamondback Moth and other Crucifer Pests: Proceedings of the 2nd International Workshop. Asian Vegetable Research and Development Centre, 10-14th December 1990, Shanhua, Taiwan

Grieg-Smith, P. (1983) Quantitative Plant Ecology. pp. 8-10. Oxford, UK, Blackwell Science.

Gupta, V.K. (1974). Studies on certain porizontine ichneumonids reared from economic hosts (parasitic Hymenoptera). Oriental Insects 3, 99-116.

Heckel, D.G., Tabashnik, B.E., Liu, Y.B., Gahan, L.J., Shelton, A.M., Zhao, J.Z. \& Baxter, S.W. (2004) Diamondback moth resistance to Bt: relevance of genetics and molecular biology to detection and management. pp. 27-36 in Endersby, N.M. \& Richland, P.M. (Eds) The management of diamondback moth and other crucifer pests: Proceedings of the 4th International Workshop. Department of Natural Resources and Environment, 26-29th November 2001, Melbourne, Australia.

Hickman, J.M. \& Wratten, S.D. (1996) Use of Phacelia tanacetifolia strips to enhance biological control of aphids by hoverflies larvae in cereal fields. Journal of Economic Entomology 89, 832-840.

Hooks, C.R.R. \& Johnson, M.W. (2003) Impact of agricultural diversification on the insect community of cruciferous crops. Crop Protection 22, 223-238.

Idris, A.B. \& Grafius, E. (1995a) Wildflowers as nectar sources for Diadegma insulare (Hymenoptera, Ichneumonidae), a parasitoid of diamondback moth (Lepidoptera, Yponomeutidae). Environmental Entomology 24, 1726-1735.
Idris, A.B. \& Grafius, E. (1995b) Alternative host of Diadegma insulare (Hymenoptera: Ichneumonidae), a parasitoid of diamondback moth, Plutella xylostella (Lepidoptera: Plutellidae). Pakistan Journal of Biological Sciences 4, 1235-1239.

Ivens, G.W. (1967) East African Weeds and their Control. 244 pp. Nairobi, Kenya, Oxford University Press.

Kahuthia-Gathu, R., Löhr, B., Poehling, H.M. \& Mbugua, P.K. Diversity and role of wild crucifers in the major cabbage and kale growing areas of Kenya. Proceedings of the 5th International Workshop on Management of the Diamondback Moth and Other Crucifer Insect Pests. 24-27th October 2006, Beijing, China, in press.

Karieva, P. (1983) Influence of vegetation texture on herbivore populations: resource concentration and herbivore movement. pp. 259-289 in Denno, R.F. \& McClure, M.S. (Eds) Variable Plants and Herbivores in Natural and Mananged Systems. New York, Academic Press.

Kfir, R. \& Thomas, J. (2001) Biological control of diamondback moth on St. Helena Island with parasitoids supplied by ARC-PPRI, Pretoria, Plant Protection News. Bulletin of the ARC Plant Protection Research Institute 59, 12-13.

Kibata, G.N. (1996) Diamondback moth Plutella xylostella L. (Lepidoptera: Yponomeutidae), a problem pest of Brassica crops in Kenya. pp. 1-11 in Farrell, G. \& Kibata, G.N. (Eds) Proceedings of 1st Biennial Crop Protection Conference. 27-28th March 1996, Nairobi, Kenya.

Kremen, C., Williams, N.M. \& Thorp, R.W. (2002) Crop pollination from native bees at risk from agricultural intensification. Proceedings of National Academy of Science USA 99, 16816-16821.

Kroschel, J. (1993) Integrierter Pflanzenschutz im Kartoffelanbau der Republik Yemen unter besonderer Berüchsichtigung der Integrierten Biologischen Bekämpfung der Kartoffelmotte (Phthorimaea operculella (Zeller). Pp. 241. Weikersheim, Germany, Josef Margraf.

Kruess, A. \& Tscharntke, T. (2000) Species richness and parasitism in fragmented landscape: experiments and field studies with insects on Vicia faba. Oecologia 122, 129-137.

Lamb, R.J. (1989) Entomology of oilseed Brassica crops. Annual Review of Entomology 34, 211-229.

Landis, D.A., Wratten, S.D. \& Gurr, G.M. (2000) Habitat management to conserve natural enemies of arthropod pests in agriculture. Annual Review of Entomology 45, 175201.

Lee, J.C., Andow, D. \& Heimpel, G. (2006) Influence of floral resources on sugar feeding and nutrient dynamics of a parasitoid in the field. Ecological Entomology 31, 470-480.

Liljesthrom, G., Minervino, E., Castro, D. \& Gonzalez, A. (2003) La communidad de arenas del provinio de Buenos Aires, Argentina. Neotropica Entomology 3, 197-210.

Liu, Y.B., Tabashnik, B.E. \& Johnson, M.W. (1995) Larval age affects resistance to Bacillus thuringiensis in diamondback moth (Lepidoptera: Plutellidae). Journal of Economic Entomology 88, 788-792.

Löhr, B. \& Rossbach, A. (2004) Diamondback moth Plutella xylostella (L.) on peas in Kenya: Impact of the host shift on the pest and its parasitoid. pp. 133-139 in The Management of Diamondback Moth and Other Crucifer Pests: Proceedings of the 4th International Workshop. Department of Natural Resources and Environment, 26-29th November 2001, Melbourne, Australia.

Löhr, B., Gathu, R., Kariuki, C., Obiero, J. \& Gichini, G. (2007) Impact of an exotic parasitoid on Plutella xylostella (Lepidoptera: Plutellidae) population dynamics, damage 
and indigenous natural enemies in Kenya. Bulletin of Entomological Research 97, 337-350.

Longley, M., Jepson, P.C. \& Sotherton, N. (1997) Temporal and spatial changes in aphid and parasitoid populations following applications of deltamethrin in winter wheat. Entomologia Experimentalis et Applicata 83, 41-52.

Magurran, A.E. (1988) Ecological Diversity and its Measurement. 179 pp. Princeton, NJ, Princeton University Press.

Marino, P.C. \& Landis, D.A. (1996) Effect of landscape structure on parasitoids diversity and parasitism in agroecosystems. Ecological Applications 6, 276-284.

Mohan, N. \& Gujar, G.T. (2003) Local variation in susceptibility of the diamondback moth, Plutella xylostella (Linneaus) to insecticides and detoxifying enzymes. Crop Protection 22, 495-504.

Momanyi, C.M., Löhr, B. \& Gitonga, L. (2006) Biological impact of the exotic parasitoid, Diadegma semiclausum (Hellén) of diamondback moth, Plutella xylostella L., in Kenya. Biological Control 38, 254-263.

Montana, C. \& Valiente-Banuet, A. (1998) Floristic and life-form diversity along an altitudinal gradient in an inter-tropical semi arid Mexican region. Southwestern Naturalist 43, 25-39.

Norris, R.F. \& Kogan, M. (2000) Interactions between weeds, arthropod pests and their natural enemies in managed ecosystems. Weed Science 48, 94-158.

Norris, R.F. \& Kogan, M. (2005) Ecology and interactions between weeds and arthropods. Annual Review of Entomology 50, 479-503.

Oduor, G.I., Löhr, B. \& Seif, A.A. (1996) Seasonality of major cabbage pests and incidence of their natural enemies in Central Kenya. pp. 37-42 in Sivapragasam, A., Kole, W.H., Hassan, A.K. \& Lim, G.S. (Eds) The Management of Diamondback Moth and Other Crucifer Pests: Proceedings of the 3rd International Workshop. 29th October-1st November 1996, Kuala Lumpur, Malaysia.

Ohara, Y., Takafuji, A. \& Takabayshi, J. (2003) Response to host infested plants in females of Diadegma semiclausum Hellén (Hymenoptera: Ichneumonidae). Applied Entomology and Zoology 38, 157-162.

Olson, D.M. \& Wäckers, F. (2007) Management of field margins to maximize multiple ecological services. Journal of Applied Ecology 44, 13-21.

Oruku, L. \& Ndung'u, B. (2001) Final socio-economic report for the peri-urban vegetable IPM thematic cluster. 49 pp. Nairobi, Kenya, CABI Africa Regional Centre Report.

Pickett, S.T.A. \& Thompson, J.N. (1978) Patch dynamics and the design of nature reserves. Biological Conservation 13, 27-37.

Purvis, A. \& Hector, A. (2000) Getting the measure of diversity. Nature 405, 212-218.

Quayle, D., Regniere, J., Cappucino, N. \& Dupont, A. (2003) Forest composition, host-population density and parasitism of spruce budworm Choristoneura fumiferana eggs of Trichogramma minutum. Entomologia Experimentalis et Applicata 107, 215-227.

Reddy, G.V.P., Tabone, E. \& Smith, M. (2004) Mediation of host selection and oviposition behaviour of the diamondback moth Plutella xylostella and its predator Chrysoperla carnea by chemical cues from cole crops. Biological Control 29, 270277.

Root, R.B. (1973) Organization of a plant-arthropod association in simple and diverse habitats: the fauna of collards (Brassica oleracea). Ecological Monographs 43, 94-125.

Root, R.B. \& Kareiva, P.M. (1984) The search for resources by cabbage butterflies (Pieris rapae), ecological consequences and adaptive significance of markovian movements in a patchy environment. Ecology 65, 147-165.

Rosenzweig, M.L. (1995) Species diversity gradients: we know more and less than we thought. Journal of mammalogy 73, 715-730.

Rossbach, A., Löhr, B. \& Vidal, S. (2005) Generalism versus specialism: Responses of Diadegma mollipla (Holmgren) and Diadegma semiclausum (Hellén), to the host shift of the diamondback moth (Plutella xylostella L.) to peas. Journal of Insect Behaviour 18, 491-503.

Russell, E.P. (1989) Enemies hypothesis: A review of the effect of vegetational diversity of predatory insects and parasitoids. Environmental Entomology 18, 590-599.

Sarfraz, M. \& Keddie, B.A. (2005) Conserving the efficacy of insecticides against Plutella xylostella (L.) (Lepidoptera: Plutellidae). Journal of Applied Entomology 129, 149-157.

SAS Institute Inc. (2004) Version 9.1 SAS/STAT Users Guide. Vol. 1 \& 2. Cary, NC, USA.

Sastrosiswojo, S. \& Sastrodihardjo, S. (1986) Status of biological control of diamondback moth by introduction of parasitoid Diadegma eucerophaga in Indonesia. pp. 185-194 in Talekar, N.S. \& Griggs, T.D. (Eds) Diamondback Moth Management: Proceedings of the 1st International Workshop. AVRDC publication, 11-15th March 1985, Tainan, Taiwan.

Shelton, A.M. (2004) Management of diamondback moth: déjà vu all over again? pp. 3-8 in Endersby, N.M. \& Ridland, P.M. (Eds) The Management of Diamondback Moth and Other Crucifer Pests: Proceedings of the 4th International Workshop. Department of Natural Resources and Environment, 2629th November 2001, Melbourne, Australia.

Simmons, M. \& Cowling, R.M. (1996) Why is the Cape peninsula so rich in plant species? An analysis of the independent diversity components. Biodiversity and Conservation $5,552-573$.

Stapel, J.O., Cortesero, A.M., de Moraes, C.M., Tumlinson, J.H. \& Lewis, W.J. (1997) Extra floral nectar, honeydew, and sucrose effects on searching behaviour and efficiency of Microplitis croceipes (Hymenoptera: Braconidae) in Cotton. Environmental Entomology 26, 617-623.

Steffan-Dewenter, I., Munzenberg, U. \& Tscharntke, T. (2001) Pollination, seed set and seed predation on a landscape scale. Proceedings of Royal Society of London 268, 1685-1690.

Suddarapandian, S. \& Swamp, P.S. (2000) Forest ecosystem structure and composition along an altitudinal gradient in the Western Ghats South India. Journal of Tropical Forest Science 12, 104-123.

Tabashnik, B.E., Carriere, Y., Dennely, T.J., Morio, S., Sisterson, M., Roush, R.T., Shelton, A.M. \& Zhao, J.Z. (2003) Insect resistance to transgenic Bt crops: lessons from the laboratory and field. Journal of Economic Entomology 96, 1031-1038.

Tahvanainen J.O. \& Root R.B. (1972) Influence of vegetational diversity on the population of a specialised herbivore Phyllotreta cruciferae. Oecologia 10, 321-346.

Talekar, N.S. \& Hu, W.J. (1966) Characteristics of parasitism of Plutella xylostella (Lep., Plutellidae) by Oomyzus sokolowskii (Hym., Eulophidae). Entomophaga 41, 45-52.

Talekar, N.S. \& Shelton, A.M. (1993) Biology, ecology and management of the diamondback moth. Annual Review of Entomology 38, 275-301.

Thies, C. \& Tscharntke, T. (1999) Landscape structure and biological control in agroecosystems. Science 285, 893-895.

Thompson, D.B., Walker, L.R., Landau, F.H. \& Stark, L.R. (2005). The influence of elevation, shrub species and 
biological soil crust on fertile islands in Mojave Desert USA. Journal of Arid Environments 61, 609-629.

Tscharntke, T. \& Kruess, A. (1999) Habitat fragmentation and biological control. pp. 190-205 in Hawkins, B.A. \& Cornell, H.V. (Eds) Theoretical Approaches to Biological Control. Cambridge, UK, Cambridge University Press.

Tscharntke, T., Klein, A.M., Kruess, A., Steffan-Dewenter, I. \& Thies, C. (2005) Landscape perspectives on agricultural intensification and biodiversity ecosystem service management. Ecology Letters 8, 857-874.

Verkerk, R.H.J. \& Wright, D.J. (1997) Field-based studies with diamondback moth tritrophic system in Cameron Highlands of Malaysia: Implications for pest management. International Journal of Pest Management 43, 27-33.

Vickers, R.A., Furlong, M.J., White, A. \& Pell, J.K. (2004) Initiation of fungal epizootics in diamondback moth populations within a large field cage: proof of concept of auto-dissimination. Entomologia Experimentalis et Applicata 111, 7-17.

Wäckers, F.L. \& van Rijn, P.C.J. (2005) Food for protection: an introduction. pp. 1-14 in Wäckers, F.L., van Rijn, P.C.J. \& Bruin, J. (Eds) Plant Provided Food for Carnivorous Insects: A
Protective Mutualism and its Applications. New York, Cambridge University Press.

Wang, X.G. \& Keller, M.A. (2002) A comparison of host searching efficiency of two larval parasitoids of Plutella xylostella. Ecological Entomology 27, 105-114.

Winkler, K., Wäckers, F.L., Stingli, A. \& van Lenteren, J.C. (2005) Plutella xylostella diamondback moth and its parasitoid Diadegma semiclausum show different gustatory and longevity responses to a range of nectar and honeydew sugars. Entomologia Experimentalis et Applicata 115, 187-192.

Wolfe, L.M. (2002) Why Alien Invaders Succeed: Support for the Escape-from-Enemy Hypothesis. The American Naturalist 160, 705-711.

Yann, C., Kruess, A. \& Tscharntke, T. (2007) Local and landscape factors in differentially managed arable fields affects the insect herbivore community of a non-crop plant species. Journal of Applied Ecology 44, 22-28.

Zhao, J.Z., Ayers, G.S., Grafius, E.J. \& Stehr, F.W. (1992) Effects of neighbouring nectar-producing plants on populations of pest Lepidoptera and their parasitoids in broccoli plantings. Great Lakes Entomology 25, 253-258. 